\title{
Cekaman Garam NaCl danTeknik Aplikasi Azolla pada Tanaman Padi
}

\section{(NaCl Salt Stress and Azolla Application Techniques in Rice Plants)}

\author{
Fitri Krismiratsih $^{1 \star}$, Sugeng Winarso ${ }^{2}$, Slamerto ${ }^{2}$ \\ (Diterima Juli 2019/Disetujui Maret 2020)
}

\begin{abstract}
ABSTRAK
Upaya peningkatan potensi produksi beras dapat dilakukan dengan ekstensifikasi pada lahan salin yang kurang produktif. Salinitas menjadi masalah utama dalam pertumbuhan sebagian besar tanaman. Azolla adalah tanaman yang sensitif terhadap salinitas, tetapi jika diaplikasikan dengan baik ia dapat tumbuh secara optimal pada tingkat salinitas tinggi. Tujuan penelitian ini adalah untuk mendapatkan teknik aplikasi azolla yang efektif dalam meningkatkan adaptasi tanaman padi pada kondisi tanah tercekam garam $\mathrm{NaCl}$. Rancangan percobaan yang diguanakan adalah Rancangan Acak Kelompok (RAK) dengan 2 faktor dan 3 ulangan. Faktor pertama adalah teknik aplikasi azolla: azolla segar yang dikomposkan, azolla segar dibenamkan, dan azolla segar sebagai penutup tanah. Faktor kedua adalah tingkat cekaman garam $\mathrm{NaCl}$, yaitu kontrol $\mathrm{DHL} 0$, 2, 4, dan $8 \mathrm{dS} \mathrm{m}^{-1}$. Kemampuan adaptasi tanaman padi didasarkan pada variabel laju pertumbuhan tinggi tanaman, jumlah anakan, bobot kering brangkasan, bobot kering akar, kerapatan stomata, klorofil daun (SPAD), umur berbunga, jumlah gabah bernas per malai, dan indeks panen. Hasil penelitian menunjukkan bahwa perlakuan cekaman garam hingga $2 \mathrm{dS} \mathrm{m}^{-1}$ justru meningkatkan pertumbuhan padi, khususnya pada tenik aplikasi azolla yang dikomposkan dulu. Peningkatan cekaman hingga 4 dan $8 \mathrm{dS} \mathrm{m}^{-1}$ berpengaruh buruk pada komponen vegetatif, fisiologi, dan hasil tanaman padi. Semakin kuat cekaman garam akan menurunkan semua variabel pertumbuhan tanaman, kecuali umur berbunga yang justru menunjukkan adanya percepatan pembungaan. Aplikasi azolla yang dikomposkan dulu dapat meningkatkan bobot kering akar dan aplikasi azolla segar sebagai penutup tanah mampu meningkatkan jumlah gabah bernas per malai.
\end{abstract}

Kata kunci: azolla, cekaman, $\mathrm{NaCl}$, padi

\section{ABSTRACT}

Efforts to increase production potential can be carried out by extensification in a less productive saline land. Salinity is a major problem in the growth of most plants. Azolla is a plant that is sensitive to salinity, but if it is applied well, it can grow optimally at high salinity levels. The purpose of this study is to obtain an azolla application technique that is effective in increasing the adaptation of rice plants to $\mathrm{NaCl}$ saline soil conditions. The experimental design used was Randomized Block Design (RBD) with 2 factors and 3 replications. The first factor was the azolla application technique consisted of 3 levels: fresh azolla composted, fresh azolla immersed, and fresh azolla as a ground cover. The second factor was the levels of $\mathrm{NaCl}$ salt stress consisted of 4 levels: control DHL $0,2,4$, and $8 \mathrm{dS}^{-1}$. The adaptation ability of rice plants based on variable plants height growth rate, number of tillers, strove dry weight, root dry weight, stomata density, leaf chlorophyll (SPAD), age of flowering, number of paddy grain, and harvest index. The results showed how to test content up to $2 \mathrm{dS} \mathrm{m}^{-1}$ which increased rice growth especially the application of azolla composted. Increasing stress to 4 and $8 \mathrm{dS} \mathrm{m}^{-1}$ showed bad effects on vegetative, physiology, and yields of rice components. The stronger of salt stress the higher all plants growth variables except the age of flowering that actually showed the acceleration of flowering. Application of composted azolla can increase the root dry weight and azolla as a ground cover can increase the numbers of paddy grains.

Keywords: azolla, $\mathrm{NaCl}$, rice, stress

\section{PENDAHULUAN}

Salah satu upaya peningkatan produksi pertanian, khususnya beras, adalah dengan cara ekstensifikasi lahan. Lahan-lahan produktif pada saat ini banyak yang beralih fungsi menjadi kawasan perumahan maupun industri. Potensi ekstensifikasi tersebut pada lahan-

1 Sekolah Pascasarjana, Fakultas Pertanian, Universitas Jember, Jl. Kalimantan No. 37, Jember 68121

2 Pusat Pengembangan IImu Pengetahuan dan Teknologi, Universitas Jember, Jl. Kalimantan No. 37, Jember 68121

* Penulis Korespondensi:

E-mail: fitri.krismiratsih@gmail.com lahan yang kurang produktif, yang umumnya mempunyai satu atau beberapa faktor pembatas dalam kegiatan budi daya. Tanah salin merupakan salah satu contohnya dan salinitas merupakan faktor pembatas abiotik utama dalam menurunkan pertumbuhan dan produksi tanaman. Salinitas tinggi dapat menurunkan produksi tanaman (Temel et al. 2016; Alcívar et al. 2018; Suárez-Hernández et al. 2019), khususnya di daerah kering; menyebabkan ketidaksetimbangan ion/hara, tekanan osmotik, dan oksidatif dalam jaringan tanaman (Zhu 2001); menghambat sintesis pigmen fotosintesis dan proses fotosintesis (El-Ramady et al. 2018), serta menurunkan air tanah atau meningkatkan konsentrasi ion dalam jaringan tanaman ke tingkat 
yang merusak metabolisme (Kalaji \& Pietkiewicz 1993).

Penghambatan pertumbuhan karena paparan salinitas jangka panjang dapat menimbulkan efek osmosis pada ketersediaan air, pengurangan asimilasi bersih, efek ion spesifik, dan ketidakseimbangan ion karena gagguan penyerapan ion-ion esensial pada tanaman (Ashraf 2009). Kandungan $\mathrm{Cl}$ yang tinggi di dalam tanah akan memengaruhi penyerapan $\mathrm{NO}_{3}$ oleh tanaman sehingga terjadi diferensiasi unsur nitrogen, selain itu penambatan nitrogen secara biologis dan mineralisasi di dalam tanah akan terhambat karena ion $\mathrm{Na}^{+}$dan $\mathrm{Cl}^{-}$yang berlebihan (Grattan \& Grieve 1998; Thohiron \& Prasetyo 2012). Banyak spesies tanaman yang mengalami penurunan pertumbuhan ketika terkena stres salinitas. Tanaman padi tergolong tanaman yang agak tahan pada kondisi salin, namun pada kondisi salinitas $4 \mathrm{dS} / \mathrm{m}$ akan menurunkan produksi sebesar $10 \%$. Semakin tinggi salinitas maka penurunan hasilnya juga akan semakin meningkat. Kondisi salinitas di atas $10 \mathrm{dS} / \mathrm{m}$ mampu menurunkan hasil padi lebih dari $50 \%$ (FAO 2005).

Lahan-lahan salin ini banyak dijumpai pada daerahdaerah dengan curah hujan rendah, irigasi, dan drainase buruk atau karena pengaruh langsung air laut. Luas lahan salin setiap tahunnya mengalami peningkatan. Berdasarkan data FAO (2014), lebih dari 6\% luas lahan pertanian di dunia telah terpengaruh oleh salinitas atau lebih dari 800 juta ha dan menurunkan pendapatan dari sektor pertanian. Luas lahan salin di Indonesia sendiri adalah 440.300 ha dengan 300.000 ha masuk ke dalam kriteria agak salin dan 140.300 ha masuk ke dalam kategori salin (Purwaningrahayu 2016).

Alcívar et al. (2018) menggunakan kombinasi biochar, senyawa humik, dan gipsum untuk memperbaiki sifat tanah salin-sodik dalam meningkatkan pertumbuhan dan kualitas benih gandum. Desokya et al. (2018) berdasarkan hasil penelitiannya merekomendasikan menggunakan senyawa humik dan ekstrak daun kelor untuk tanaman sorgum pada tanah salin.

Pengembangan budi daya tanaman padi dengan melakukan pengelolaan nutrisi tanaman yang baik dapat dilakukan sebagai upaya untuk mengurangi ionion yang sifatnya toksik dan meningkatkan nutrisi yang dibutuhkan oleh tanaman. Penambahan bahan ameliorant organik berupa azolla sebagai upaya untuk meningkatkan ketersediaan nitrogen yang akan dimanfaatkan oleh tanaman, dan memperbaiki sifat fisik tanah karena dengan penambahan bahan organik mampu meningkatkan kemampuan tanah untuk mengikat dan menahan air, dan juga sebagai perekat, pembentuk, dan pemantap agregat tanah dengan memperbaiki sifat tanah diharapkan dapat mendukung pertumbuhan tanaman (Wahyuningsih et al. 2017).

Azolla relatif sensitif terhadap garam, namun budi daya di lingkungan garam dalam jangka waktu 2 tahun berturut-turut menurunkan kadar garam $0,35-0,15$ dan tingkat salinitas sebesar $71,4 \%$ yang adalah 1,8 kali lebih cepat dibandingkan dengan melalui pencucian air dan juga mengurangi konduktivitas listrik dan $\mathrm{pH}$ tanah masam (Raja et al. 2012). Selain itu, azolla merupakan tumbuhan air yang mengikat nitrogen bebas dari udara dengan bantuan ganggang hijau biru Anabaena azollae, selanjutnya dengan cepat menguraikan dan melepaskan senyawa nitrogen tersebut ke dalam tanah dan bermanfaat bagi tanaman padi. Penggunaan Azolla 20 ton/ha dapat menghemat pupuk Nitrogen $60 \mathrm{~kg} / \mathrm{ha}$ dan meningkatkan produksi gabah basah $21 \%$ (Husen et al. 2016).

Tujuan penelitian ini adalah untuk mengetahui pengaruh berbagai teknik aplikasi azolla pada tanah tercekam garam $\mathrm{NaCl}$ pada komponen vegetatif, fisiologi, dan hasil tanaman padi.

\section{METODE PENELITIAN}

Penelitian ini dilaksanakan di rumah plastik pada bulan Oktober 2018-Februari 2019 di lahan jl. Parangtritis, Kelurahan Antirogo Sumbersari, Jember. Sementara itu, pengamatan dilakukan di laboratorium Tanaman dan Bioscience, Politeknik Negeri Jember.

Bahan-bahan yang digunakan dalam percobaan adalah benih padi varietas Ciherang, kompos azolla, azolla segar, garam $\mathrm{NaCl}$, Urea, SP36, $\mathrm{KCl}$, dan pestisida, sedangkan alat-alat yang digunakan adalah penggaris kain, SPAD Konica Minolta, Lightx meter LX103, Mikroskop Olympus CX31RBSFA, oven, dan timbangan analitik.

Sebelum pelaksanaan penelitian, dilakukan perbanyakan Azolla pinata pada kolam budi daya selama 3 minggu untuk mendapatkan semua bahan penelitian. Sebagian hasil panen langsung dilakukan pengomposan dengan tahapan ditiriskan, dikeringkan, fermentasi dengan dipercepat oleh penambahan EM4, dan selama pengomposan dilakukan pembalikan untuk mendapatkan dekomposisi dan hasil yang relatif sama. Pengomposan dihentikan pada saat warna bahan sudah menjadi hitam dan dilanjutkan dengan pengeringan untuk mengurangi kadar air sehingga siap digunakan untuk bahan perlakuan. Persiapan juga dilakukan untuk mendapatkan bibit padi varietas Ciherang, media tanam dalam pot dengan diameter 20 $\mathrm{cm}$, aplikasi azolla sesuai dengan perlakuan sebanyak $125 \mathrm{~g}$ setiap media tanam atau pot pada masingmasing perlakuan azolla. Penanaman 2 bibit setiap pot, kemudian dilakukan pemupukan dengan dosis urea $1,87 \mathrm{~g} \mathrm{tan}^{-1}$, SP-36 0,625 g tan-1, KCL 0,625 g tan-1, penyulaman 3 hari sekali, pengendalian hama dan penyakit, serta panen.

Percobaan menggunakan Rancangan Acak Kelompok (RAK) dengan 2 faktor perlakuan, yaitu teknik atau cara aplikasi azolla dengan 3 taraf perlakuan dan tingkat cekaman salinitas dengan 4 taraf perlakuan, sehingga terdiri atas 12 kombinasi perlakuan yang diulang 3 kali. Teknik atau cara aplikasi azolla yang diterapkan adalah: A1, azolla segar yang dikomposkan (kompos azolla); A2, azolla segar 
dibenamkan; dan A3, azolla segar sebagai penutup tanah, sedangkan untuk faktor tingkat salinitas terdiri atas S0 (0 dS m-1 kontrol); S1 (2 dS m-1); S2 (4 dS m1); dan S3 (8 dS $\left.\mathrm{m}^{-1}\right)$. Analisis data hasil penelitian dilakukan menggunakan analisis ragam/analysis of variance (ANOVA) dan DMRT 5\%.

\section{HASIL DAN PEMBAHASAN}

\section{Karakter Agronomis Tanaman Padi}

Laju pertumbuhan tinggi tanaman, jumlah anakan, bobot kering brangkasan (Tabel 1), dan bobot kering akar tanaman padi (Tabel 2) terhambat secara nyata oleh peningkatan cekaman garam $\mathrm{NaCl}$ (salinitas), sedangkan teknik aplikasi azolla yang berbeda tidak berpengaruh nyata pada karakter agronomis tanaman padi varietas Ciherang. Evaluasi interaksi antara cekaman garam $\mathrm{NaCl}$ dengan teknik aplikasi juga tidak berpengaruh nyata pada karakter agronomis tanaman padi tersebut, kecuali bobot kering akar tanaman.

Peningkatan garam $\mathrm{NaCl}$ berdampak buruk pada pertumbuhan tanaman yang meliputi pertumbuhan tinggi tanaman, jumlah anakan, dan bobot kering brangkasan. Pertumbuhan tanaman yang dikatakan baik bisa dilihat dari laju pertumbuhan tinggi tanaman yang optimal karena dengan tanaman tumbuh dengan optimal diharapkan akan memberikan hasil produksi yang optimal juga.

Tinggi tanaman yang paling optimal adalah pada perlakuan garam $\mathrm{NaCl} 0 \mathrm{dS}^{-1}$ dengan laju pertumbuhan $14,62 \mathrm{~cm}$ per minggu, namun tidak berbeda nyata dari perlakuan $2 \mathrm{dS} \mathrm{m}^{-1}$ dengan laju pertumbuhan $13,48 \mathrm{~cm}$ per minggu, namun berbeda nyata dari perlakuan $8 \mathrm{dS} \mathrm{m}^{-1}$ dengan laju pertumbuhan tinggi tanaman $10,50 \mathrm{~cm}$ per minggu (Tabel 1). Pada tingkat cekaman garam $\mathrm{NaCl} 8 \mathrm{dS} \mathrm{m}^{-1}$ menunjukkan gejala tanaman akibat tercekam salinitas, yaitu tanaman padi tumbuh menjadi lebih kerdil, daun menunjukkan warna hijau tua, dan ujung daun menguning seperti terbakar (Muharam \& Saefudin 2016). Hal ini menunjukkan bahwa tanaman padi tidak toleran terhadap cekaman garam $\mathrm{NaCl} 8 \mathrm{dS} \mathrm{m}^{-1}$ namun masih toleran terhadap tingkat cekaman $4 \mathrm{dS} \mathrm{m}^{-1}$, yang hal ini disebabkan karena tanaman padi Ciherang tergolong ke dalam kelompok tanaman dengan adaptasi terhadap salin toleran sedang (Mindari 2009).

Jumlah anakan terbanyak adalah pada perlakuan 2 dS $\mathrm{m}^{-1}$ dengan jumlah 34,28 anakan, sedangkan jumlah anakan terendah adalah pada perlakuan $8 \mathrm{dS}$ $\mathrm{m}^{-1}$. Akan tetapi, data ini tidak sejalan dengan data bobot kering brangkasan di mana bobot brangkasan yang paling tinggi ditemukan pada perlakuan kontrol dengan $0 \mathrm{dS} \mathrm{m}^{-1}$ dengan bobot brangkasan sebesar $100,94 \mathrm{~g}$ (a) dan yang paling rendah adalah pada perlakuan $8 \mathrm{dS} \mathrm{m}^{-1}$ dengan bobot brangkasan $45,06 \mathrm{~g}$ (b). Semakin meningkat cekaman garam $\mathrm{NaCl}$ maka bobot kering brangkasan juga semakin menurun dan hal ini erat kaitannya dengan efek salinitas yang adalah toksisitas ion $\mathrm{Na}$ dan $\mathrm{Cl}$, penurunan penyerapan air karena perbedaan tekanan osmotik antara akar dan larutan air tanah, dan hambatan penyerapan unsurunsur hara (Dinata 1985; FAO 2005; Barus 2016). Dengan adanya efek salinitas tersebut maka akan meyebabkan proses metabolisme tanaman akan terganggu, dan mengakibatkan jumlah asimilat yang dihasilkan oleh tanaman juga akan berkurang dan menurunkan bobot brangkasan tanaman (Ma'ruf 2016).

Organ tanaman yang berfungsi sebagai penyerapan air dan hara dari dalam tanah untuk selanjutnya ditranslokasikan ke dalam tanaman serta sebagai sensor paling utama terhadap perubahan hara, ketersediaan air, dan salinitas adalah akar. Apabila

Tabel 1 Tinggi tanaman, jumlah anakan, dan bobot kering brangkasan tanaman padi pada tingkat cekaman garam $\mathrm{NaCl}$

\begin{tabular}{cccc}
\hline Perlakuan garam NaCl & $\begin{array}{c}\text { Laju pertumbuhan tinggi } \\
\left.\text { tanaman (cm.minggu }{ }^{-1}\right)\end{array}$ & $\begin{array}{c}\text { Jumlah anakan } \\
(6 \mathrm{MST})\end{array}$ & $\begin{array}{c}\text { Bobot kering brangkasan } \\
\left(\text { g.tanaman }^{-1}\right)\end{array}$ \\
\hline $0 \mathrm{dS} \mathrm{m}^{-1}$ & $14,62^{\mathrm{a}}$ & $29,00^{\mathrm{bc}}$ & $100,94^{\mathrm{a}}$ \\
$2 \mathrm{dS} \mathrm{m} \mathrm{m}^{-1}$ & $13,84^{\mathrm{ab}}$ & $34,28^{\mathrm{a}}$ & $94,28^{\mathrm{ab}}$ \\
$4 \mathrm{dS} \mathrm{m}^{-1}$ & $12,72^{\mathrm{b}}$ & $33,33^{\mathrm{ab}}$ & $81,78^{\mathrm{b}}$ \\
$8 \mathrm{dS} \mathrm{m}{ }^{-1}$ & $10,50^{\mathrm{c}}$ & $25,22^{\mathrm{c}}$ & $45,06^{\mathrm{c}}$ \\
\hline $\mathrm{Sd}$ & 0,38 & 1,45 & 5,5808 \\
\hline
\end{tabular}

Keterangan: Angka-angka yang diikuti oleh huruf yang sama dalam satu kolom menunjukkan perbedaan tidak nyata pada uji jarak berganda duncan $5 \%$.

Tabel 2 Bobot kering akar tanaman padi pada aplikasi azolla dan tingkat cekaman garam $\mathrm{NaCl}$

\begin{tabular}{|c|c|c|c|c|c|c|c|c|c|}
\hline \multirow{2}{*}{ Aplikasi azolla } & \multicolumn{8}{|c|}{ Tingkat cekaman garam $\mathrm{NaCl}\left(\mathrm{dS} \mathrm{m}^{-1}\right)$} & \multirow{2}{*}{ Rata-rata } \\
\hline & & & & & 4 & & & & \\
\hline Kompos & 31,00 & 34,79 & 45,50 & $\mathrm{aA}$ & 37,00 & $\mathrm{aB}$ & 25,67 & $\mathrm{aC}$ & 34,79 \\
\hline Dibenamkan & 33,33 & 31,92 & 37,50 & $\mathrm{bA}$ & 34,83 & $\mathrm{aA}$ & 22,00 & $b B$ & 31,92 \\
\hline Penutup tanah & 44,83 & 34,54 & 38,17 & bAB & 31,50 & $\mathrm{aB}$ & 23,67 & $\mathrm{aC}$ & 34,54 \\
\hline
\end{tabular}

Keterangan: Huruf kecil (vertikal) dan huruf kapital (horizontal), angka yang diikuti huruf yang berbeda menunjukkan perbedaan yang nyata menurut uji DMRT pada taraf $5 \%$. 
sumber daya alam yang tersedia berkurang maka akar akan menyesuaikan melalui perubahan morfologinya (Galvan-Ampudia et al. 2013).

Pada hasil pengamatan pada panjang akar tanaman padi ditemukan bahwa kombinasi azolla yang dibenamkan dengan tingkat cekaman garam $\mathrm{NaCl} 8 \mathrm{dS}$ $\mathrm{m}^{-1}$ menurun sebesar $52 \%$, pada perlakuan kompos azolla dan tingkat cekaman garam $\mathrm{NaCl} 8 \mathrm{dS} \mathrm{m}^{-1}$ menurun sebesar 44\%, sedangkan pada azolla sebagai penutup tanah, panjang akar tanaman padi menurun sebesar 48\% (Gambar 1). Berdasarkan hasil pengamatan pada tingkat cekaman garam $\mathrm{NaCl} 8 \mathrm{dS}$ $\mathrm{m}^{-1}$ menunjukkan bahwa aplikasi azolla sebagai kompos dan penutup tanah dapat meningkatkan adaptasi akar tanaman (Utama et al. 2009). Bobot kering brangkasan tertinggi ditemukan pada perlakuan kompos azolla dan tingkat cekaman garam $\mathrm{NaCl} 2$ dS $\mathrm{m}^{-1}$ dan yang paling rendah adalah pada azolla dibenamkan dengan garam $\mathrm{NaCl} 8 \mathrm{dS} \mathrm{m}^{-1}$.

Pada Gambar 2 terlihat bahwa kondisi tanah percobaan tercekam garam $\mathrm{NaCl}$. Penelitian yang dilakukan pada pot-pot percobaan menyebabkan permeabilitas tanah kurang baik sehingga akan menyebabkan penghambatan pertumbuhan akar (Muharam \& Saefudin 2016). Pada kondisi cekaman salinitas ini terjadi respons pemblokiran akar untuk menekan

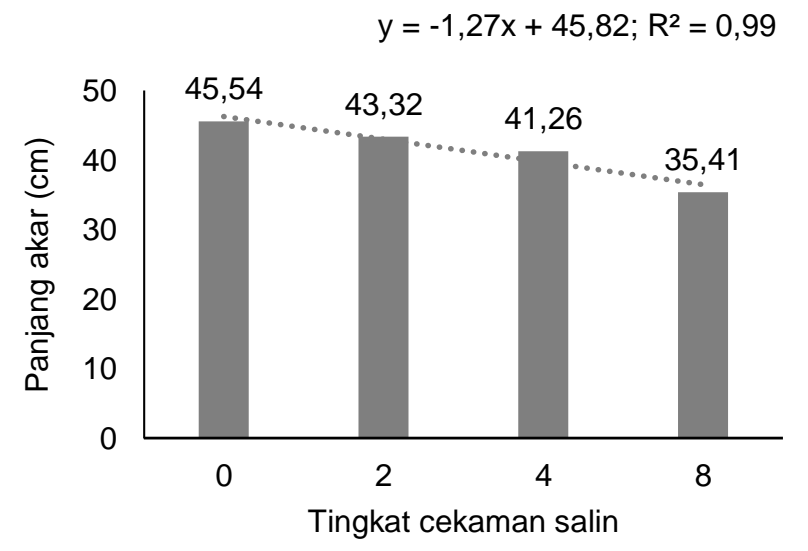

Gambar 1 Pengaruh tingkat cekaman garam $\mathrm{NaCl}$ pada panjang akar tanaman.

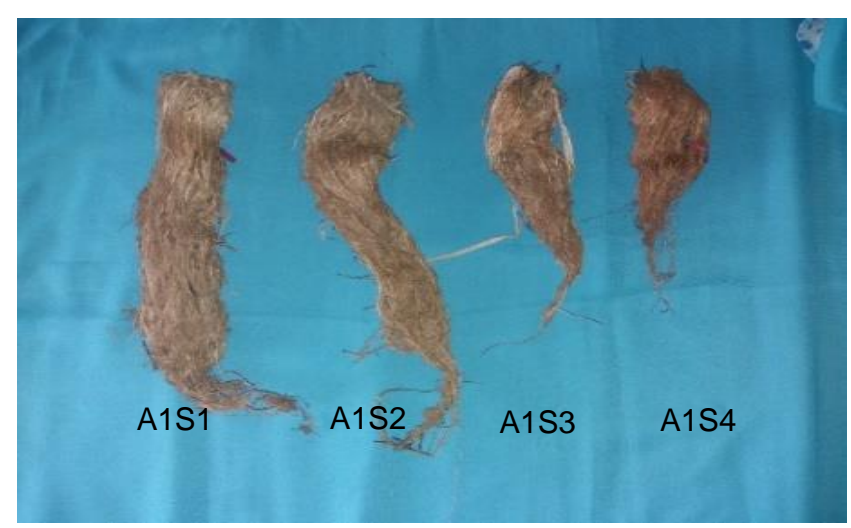

Gambar 2 Kondisi akar pada perlakuan azolla dikomposkan pada semua taraf cekaman garam $\mathrm{NaCl}$ (b). kapasitas akar untuk merespons gravimetri dan memungkinkan akar untuk menghindar dari cekaman salinitas dengan cara redistribusi auksin pada ujung akar yang menyebabkan akar menekuk pada konsentrasi garam NaCl tinggi (Galvan et al. 2013).

\section{Karakter Fisiologis Tanaman Padi}

Parameter fisiologis yang diukur dalam pengamatan fisiologis adalah kerapatan stomata dan klorofil dengan menggunakan SPAD. Parameter kerapatan stomata berdasarkan hasil uji anova dipengaruhi oleh interaksi antara azolla dan tingkat cekaman salinitas yang menunjukkan hasil yang berbeda sangat nyata, sedangkan pada komponen klorofil menunjukkan hasil yang berbeda sangat nyata pada tingkat cekaman slainitas.

Stomata adalah komponen fotosintesis dan transpirasi yang berada dalam permukaan daun berbentuk pori mikroskopis. Efek cekaman salinitas akan menurunkan jumlah stomata per satuan luas serta penutupan stomata untuk mengatur keseimbangan air (Purwaningrahayu \& Taufik 2017). Cekaman salinitas akan mengubah morfologi ukuran daun menjadi lebih kecil dan ukuran stomata juga akan menjadi lebih kecil (Barus 2016).

Berdasarkan data pada Tabel 3 menunjukkan bahwa semakin meningkat intensitas cekaman garam $\mathrm{NaCl}$ akan menurunkan jumlah stomata per satuan luas. Jumlah stomata paling banyak ditemukan pada perlakuan kompos azolla dengan tingkat cekaman garam $\mathrm{NaCl} 2 \mathrm{dS} \mathrm{m} \mathrm{m}^{-1}$, yaitu 274,04 (aA) dan tidak berbeda nyata dengan aplikasi azolla lainnya pada tingkat cekaman $2 \mathrm{dS} \mathrm{m}^{-1}$ dan yang paling rendah adalah pada tingkat cekaman garam $\mathrm{NaCl} 8 \mathrm{dS} \mathrm{m}^{-1}$ pada azolla penutup tanah, yaitu 173,02 (aC).

Penurunan jumlah stomata per satuan luas terjadi karena adanya stress osmotik akibat perbedaan potensial antara akar tanaman dan larutan tanah yang menyebabkan penutupan stomata karena kurang ekspansi sel pada ujung daun muda, selain itu penutupan stomata akan menyebabkan penurunan kehilangan air karena adanya respons asam absisat untuk respons mekanisme perlindungan akan membatasi $\mathrm{Na}$ dan $\mathrm{Cl}$ dalam daun, $\mathrm{ABA}$ juga akan membatasi transportasi dan kehilangan air dengan cara menutup stomata. Penutupan stomata juga dipengaruhi oleh adanya $\mathrm{Ca}$ dalam sitoplasma yang menyebabkan kehilangan tekanan turgor pada sel penjaga (Arifiani et al. 2018).

Pada pengamatan jumlah klorofil pada tanaman yang tercekam garam $\mathrm{NaCl}$ semakin menurunkan jumlah klorofil yang diamati dengan menggunakan SPAD (Tabel 4). Pada perlakuan tanpa cekaman garam $\mathrm{NaCl}$ atau kadar salinnya $0 \mathrm{dS} \mathrm{m}^{-1}$ menunjukkan jumlah klorofil 58,22, sedangkan pada cekaman garam $\mathrm{NaCl} 8 \mathrm{dS} \mathrm{m} \mathrm{m}^{-1}$ menurun menjadi 46,87.

Pengurangan konsentrasi klorofil pada tanaman padi dikarenakan adanya efek penghambatan akibat akumulasi ion-ion garam pada biosintesa klorofil yang berbeda. Adanya cekaman garam $\mathrm{NaCl}$ akan 
Tabel 3 Kerapatan stomata tanaman padi pada aplikasi azolla dan tingkat cekaman garam $\mathrm{NaCl}$

\begin{tabular}{|c|c|c|c|c|c|c|c|c|c|}
\hline \multirow{2}{*}{ Aplikasi azolla } & \multicolumn{8}{|c|}{ Tingkat cekaman garam $\mathrm{NaCl}\left(\mathrm{dS} \mathrm{m}^{-1}\right)$} & \multirow{2}{*}{ Rata-rata } \\
\hline & \multicolumn{2}{|c|}{0} & \multicolumn{2}{|c|}{2} & \multicolumn{2}{|c|}{3} & \multicolumn{2}{|c|}{8} & \\
\hline Kompos & 238,63 & $\mathrm{bB}$ & 274,04 & $\mathrm{aA}$ & 203,82 & $\mathrm{bC}$ & 177,48 & $\mathrm{aC}$ & 223,49 \\
\hline Dibenamkan & 229,39 & $\mathrm{bA}$ & 249,91 & $\mathrm{aA}$ & 242,27 & $\mathrm{aA}$ & 192,15 & $\mathrm{aB}$ & 228,43 \\
\hline Penutup tanah & 268,82 & $\mathrm{aA}$ & 255,27 & $\mathrm{aA}$ & 223,87 & $a B$ & 173,02 & $\mathrm{aC}$ & 230,24 \\
\hline
\end{tabular}

Keterangan: Huruf kecil (vertikal) dan huruf kapital (horisontal), angka yang diikuti huruf yang berbeda menunjukkan perbedaan yang nyata menurut uji DMRT pada taraf $5 \%$.

Tabel 4 Jumlah klorofil SPAD tanaman padi pada tingkat cekaman garam $\mathrm{NaCl}$ pada

\begin{tabular}{|c|c|}
\hline $\begin{array}{l}\text { Tingkat cekaman garam } \\
\qquad \mathrm{NaCl}\left(\mathrm{dS} \mathrm{m}^{-1}\right)\end{array}$ & Jumlah klorofil SPAD \\
\hline 0 & $58,22^{a}$ \\
\hline 2 & $55,34^{\mathrm{ab}}$ \\
\hline 4 & $48,69^{b}$ \\
\hline 8 & $46,87^{b}$ \\
\hline Sd & 2,55 \\
\hline
\end{tabular}

Keterangan: Angka-angka yang diikuti oleh huruf yang sama dalam satu kolom menunjukkan perbedaan tidak nyata pada uji jarak berganda duncan $5 \%$.

memengaruhi kekuatan pada penyusunan pigmen protein dalam menyusun kloroplas. Kloroplas yang terikat kuat akan menyebabkan kestabilan membran jarang utuh karena penyusunan komponen penyusun klorofil ini adalah komponen kompleks, bukan komponen tunggal (Ali et al. 2004).

\section{Hasil Tanaman Padi}

Komponen hasil yang diamati dalam penelitian ini adalah umur berbunga, jumlah gabah berisi per malai, dan peubah indeks panen. Azolla dan tingkat cekaman garam $\mathrm{NaCl}$ berpengaruh nyata pada jumlah gabah berisi per malai, sedangkan tingkat cekaman garam $\mathrm{NaCl}$ berpengaruh berbeda nyata pada umur berbunga dan perubahan indeks panen.

Cekaman garam $\mathrm{NaCl}$ tinggi akan menyebabkan umur berbunga menjadi lebih panjang. Pada perlakuan garam $\mathrm{NaCl} 2 \mathrm{dS} \mathrm{m} \mathrm{m}^{-1}$ ditemukan bahwa tanaman lebih awal berbunga, yaitu pada umur 72,28 HST (c) dan tidak berbeda nyata dibandingkan dengan perlakuan 0 dS $\mathrm{m}^{-1}$ dan berbeda nyata dibandingkan dengan perlakuan garam $\mathrm{NaCl} 8 \mathrm{dS} \mathrm{m}^{-1}$ yang berbunga pada umur 80,11 HST (a). Fase pertumbuhan yang sensitif terhadap salinitas salah satunya adalah fase berbunga. Tekanan salinitas dan toleransi terhadap salin adalah peningkatan musim tanam yang lebih panjang, yang usia ideal antara umur panen dan umur berbunga pada tanaman padi kurang lebih 30 hari (Zeng et al. 2002).

Penghambatan proses pembungaan pada tanaman padi pada tingkat cekaman garam $\mathrm{Na}^{+}$disebabkan oleh faktor genetik (Park et al. 2016). Lebih lanjut berdasarkan penelitian Amirjani (2010) ditemukan bahwa pada penelitian padi IR-64 di bawah kondisi cekaman garam $\mathrm{NaCl}$, tanaman mengalami keterlambatan pembungaan selama 11-19 hari. Keterlambatan umur berbunga ini terjadi karena pada tingkat cekaman tinggi, stres osmotik akan meningkat selama fase vegetatif sehingga akan berimbas pada fase generatif.

Indeks panen yang rendah pada tanaman akibat salinitas adalah akumulasi perubahan morfologis dan fisiologis tanaman, di mana salinitas akan memengaruhi perubahan morfologi, yaitu laju pertumbuhan tinggi tanaman, penurunan ukuran daun, penurunan umur berbunga, pengurangan jumlah kerapatan stomata, klorofil daun yang rendah yang akan menyebabkan gangguan proses metabolisme di dalam tanaman sehingga akan berakibat pada indeks panen yang rendah.

Indeks panen terendah ditemukan pada perlakuan $8 \mathrm{dS} \mathrm{m}^{-1}$, yaitu 25,91 dan yang tertinggi dalah pada perlakuan salinitas $0 \mathrm{dS} \mathrm{m}^{-1}$, yaitu 50,47 dan semakin meningkat tingkat cekaman salinitas akan menurunkan indeks panen tanaman padi (Tabel 5).

Jumlah gabah bernas per malai pada cekaman garam menunjukkan bahwa yang menghasilkan gabah bernas per malai paling banyak adalah pada perlakuan azolla sebagai penutup tanah pada tingkat cekaman garam $\mathrm{NaCl}$, yaitu 127,00, sedangkan pada perlakuan cekaman garam $\mathrm{NaCl} 8 \mathrm{dS} \mathrm{m}^{-1}$ menunjukkan hasil terendah pada semua perlakuan azolla (Tabel 6).

Peningkatan tingkat cekaman garam $\mathrm{NaCl}$ menyebabkan perkembangan biji terganggu, azolla dapat melepas $50-60 \% \mathrm{~N}$ tersedia ke dalam tanah setelah terdekomposisi selama 40 hari setelah aplikasi. Pembenaman kompos azolla dan azolla dibenamkan mungkin belum cukup untuk proses dekomposisi dan pelepasan hara dan dalam proses mineralisasi bahan organik juga dipengaruhi oleh frekuensi pengaplikasian unsur hara (Dewi \& Setiawati 2018).

Sejalan dengan pendapat Khoiriyyah et al. (2017) bahwa azolla dapat menyumbang $\mathrm{N}$ pada media tanam untuk pertumbuhan tanaman dan dalam penelitian menyatakan bahwa pengaplikasian azolla dapat mengurangi cekaman garam $\mathrm{NaCl}$.

\section{Korelasi Antar-Variabel}

Analisis korelasi dilakukan untuk mengetahui keeratan hubungan antara dua peubah atau lebih. Berdasarkan analisis korelasi menunjukkan bahwa peubah indeks panen berkorelasi positif dengan tinggi tanaman $\left(r=0,915^{\star *}\right)$, klorofil daun (SPAD) $\left(r=0,536^{*}\right)$, kerapatan stomata $\left(r=0,73^{* *}\right)$, bobot kering akar $(r=0,70$ $\left.{ }^{* *}\right)$, bobot kering brangkasan $\left(r=0,87^{* *}\right)$, jumlah gabah bernas per malai $\left(r=0,87^{* *}\right)$, dan berkorelasi negatif dengan umur berbunga $\left(r=89^{* *}\right)$, sedangkan dengan jumlah anakan menunjukkan nilai korelasi $\left(r=0,32^{\star *}\right)$. 
Tabel 5 Umur berbunga dan indeks panen pada cekaman garam $\mathrm{NaCl}$

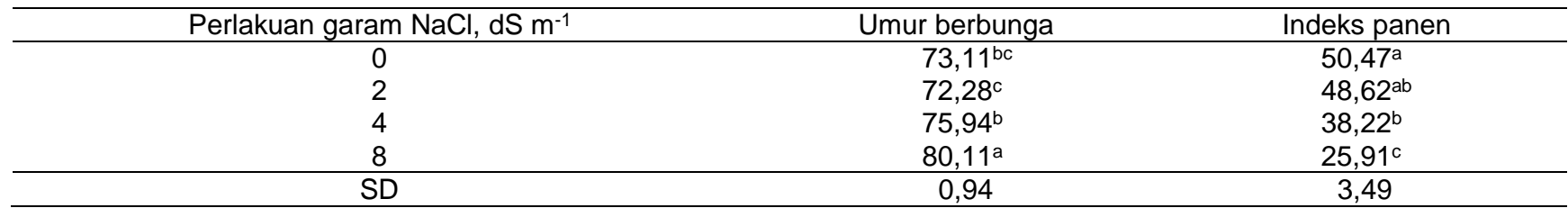

Keterangan: Angka-angka yang diikuti oleh huruf yang sama dalam satu kolom menunjukkan perbedaan tidak nyata pada uji jarak berganda duncan $5 \%$.

Tabel 6 Jumlah gabah bernas per malai pada aplikasi azolla dan tingkat cekaman garam $\mathrm{NaCl}$

\begin{tabular}{|c|c|c|c|c|c|c|c|c|}
\hline \multirow{2}{*}{ Aplikasi azolla } & \multicolumn{7}{|c|}{ Tingkat cekaman garam $\mathrm{NaCl}, \mathrm{dS} \mathrm{m}^{-1}$} & \multirow{2}{*}{ Rata-rata } \\
\hline & ( & & 2 & & & & & \\
\hline Kompos & 103,22 & $\mathrm{bA}$ & 101,83 & 90,28 & $\mathrm{aA}$ & 72,22 & $\mathrm{aB}$ & 91,89 \\
\hline Dibenamkan & 93,11 & $\mathrm{bB}$ & 118,67 & 82,39 & $\mathrm{aB}$ & 44,44 & $\mathrm{bC}$ & 84,65 \\
\hline Penutup tanah & 127,00 & $\mathrm{aA}$ & 91,17 & 83,89 & $\mathrm{aB}$ & 37,78 & $\mathrm{bC}$ & 84,96 \\
\hline
\end{tabular}

Keterangan: Angka-angka yang diikuti oleh huruf yang sama dalam satu kolom menunjukkan perbedaan tidak nyata pada uji jarak berganda duncan $5 \%$.

\section{KESIMPULAN}

Tanaman padi yang diperlakukan dengan azolla dan cekaman salinitas menunjukkan gejala tercekam pada tingkat cekaman garam $\mathrm{NaCl} 4 \mathrm{dS} \mathrm{m}^{-1}$ yang ditunjukkan dengan penurunan laju pertumbuhan tinggi tanaman, jumlah anakan, bobot kering brangkasan, bobot kering akar, kerapatan stomata, klorofil, umur berbunga, jumlah gabah berisi per malai, dan peubah indeks panen. Perlakuan cekaman garam hingga 2 dS $\mathrm{m}^{-1}$ justru meningkatkan pertumbuhan padi, khususnya pada tenik aplikasi azolla yang dikomposkan dulu. Terdapat perbedaan macam aplikasi azolla pada berbagai tingkat cekaman garam $\mathrm{NaCl}$. Pengaplikasian garam $\mathrm{NaCl}$ pada tingkat $2 \mathrm{dS} \mathrm{m}^{-1}$ dapat memperpendek umur berbuga dan pada variabel pengamatan indeks panen dan jumlah gabah bernas per malai menunjukkan hasil berbeda yang tidak nyata pada perlakuan tanpa cekaman garam.

\section{UCAPAN TERIMA KASIH}

Ucapan terima kasih kami sampaikan kepada Teknisi Laboratorium Agronomi Universitas, Laboratorium Bioscience, Politeknik Negeri Jember, dan teman-teman mahasiswa Program Magister Agronomi, Universitas Jember angkatan 2016 dan 2017 yang telah membantu selama penelitian ini berlangsung.

\section{DAFTAR PUSTAKA}

Alcívar M, Zurita-Silva A, Sandoval M, Muñoz C, Schoebitz M. 2018. Reclamation of Saline-Sodic Soils with Combined Amendments: Impact on Quinoa Performance and Biological Soil Quality. Sustainability. 10: 1-27. https://doi.org/10.3390/ su10093083
Ali Y, Aslam Z, Ashraf MY, Tahir GR. 2004. Effect of Salinity on Chlorophyll Concentration, Leaf Area, Yield and Yield Components of Rice Genotypes Grown Under Saline Environment. International Journal of Environmental Science \& Technology. 1(3): 221-225. https://doi.org/10.1007/BF033 25836

Amirjani MR. 2010. Effect of $\mathrm{NaCl}$ on Some Physiological Parameters of Rice. EBJS (European of Journal Biological Science). 3(1): 6-16. https:// doi.org/10.22146/veg.38133

Arifiani FN, Kurniasih B, Rogomulyo R. 2018. Pengaruh Bahan Organik Terhadap Pertumbuhan dan Hasil Padi (Oryza sativa L.) Tercekam Salinitas. Vegetalika. 7(3): 30-40.

Ashraf M. 2009. Biotechnological Approach of Improving Plant Salt Tolerance Using Antioxidants as Markers. Biotechnology Advances. 27(1): 84-93. https://doi.org/10.1016/j.biotechadv.2008.09.003

Barus WA. 2016. Peningkatan Toleransi Padi Sawah Di Tanah Salin Menggunakan Anti Oksidan Asam Askorbat dan Pemupukan PK Melalui Daun. [disertasi]. Medan (ID): Universitas Sumatera Utara.

Desokya ESM, Merwadb ARM, Rady MM. 2018. Natural Biostimulants Improve Saline Soil Characteristics and Salt Stressed-Sorghum Performance. Communications in Soil Science and Plant Analysis. Taylor \& Francis. 1-17.

Dewi AK, Setiawati MR. 2018. Pengaruh Pupuk Hayati Endofitik dengan Azolla Pinnata Terhadap Serapan N, N-Total Tanah, dan Bobot Kering Tanaman Padi (Oryza Sativa L.) pada Tanah Salin. Agrologia. 6(2). 54-60. https://doi.org/10.30598/a.v6i2.168

Dinata KK. 1985. Pengaruh Salinitas Terhadap Pertumbuhan dan Produksi Padi Varietas Atomita II dan IR 32. Bogor (ID): Institut Pertanian Bogor. 
El-Ramady H, Ishaal T, Elhawat N, Ghazi A, Elsakhawy T, Omara AE, El-Nahrawy S, Elmahrouk M, Abdalla N, Domokos-Szabolcsy E, Schnug E. 2018. Plant Nutrients and Their Roles Under Saline Soil Conditions. Springer Nature Singapore Pte Ltd. 297-324. https://doi.org/10.1007/978-981-10-90448_13

FAO. 2005. 20 Hal Untuk Diketahui Tentang Dampak Air Laut Pada Lahan Pertanian Profinsi NAD, Panduan Lapang FAO [Online]. Available at: http://www.fao.org/ag/tsunami/docs/20_things_on_ salinity_Bahasa.pdf [Accessed: 12 May 2018].

FAO. 2005. 20 Hal Untuk Diketahui Tentang Dampak Air Laut Pada Lahan Pertanian Profinsi NAD, Panduan Lapang FAO [Online]. Available at: http://www.fao.org/ag/tsunami/docs/20_things_on_ salinity_Bahasa.pdf [Accessed: 12 May 2018].

Galvan-Ampudia CS, Julkowska MM, Darwish E, Gandullo J, Korver RA, Brunoud G, Haring MA, Munnik T, Vernoux TC Testerink. 2013. Halotropism is a Response of Plant Roots to Avoid a Saline Environment. Current Biology. 23(20): 2044-2050. https://doi.org/10.1016/j.cub.2013. 08.042

Grattan SR, Grieve CM. 1998. Salinity-Mineral Nutrient Relations in Horticultural Crops. Scientia Horticulturae. 78(1-4): 127-157. https://doi.org/ 10.1016/S0304-4238(98)00192-7

Husen S, Ishartati E, Hartawati, Sukardi. 2016. Penerapan Azolla Pada Budi Daya Tanaman Padi Sawah. Research Report. 208-213.

Kalaji MH, Pietkiewicz S. 1993. Salinity Effect in Plant Growth and Other Physiological Process. Acta Physiologiae Plantarum. 15: 89-124.

Khoiriyyah L, Setiawati MR, Suriadikusumah A. 2017. Pengaruh $\mathrm{NaCl}$ dan Amelioran Organik Azolla Pinnata Terhadap N-Total, Ph Tanah, Serta Bobot Kering Tanaman Padi (Oryza Sativa L.) pada Inceptisols Jatinangor. Jurnal Agroekoteknologi. 9(1): 115-123.

Ma'ruf A. 2016. Respons Beberapa Kultivar Tanaman Pangan Terhadap Salinitas. Bernas. 12(3): 11-19.

Mindari W. 2009. Cekaman Garam dan Dampaknya Pada Kesuburan tanah dan Pertumbuhan Tanaman. Surabaya (ID): UPN "Veteran" Jawa Timur.

Muharam M, Saefudin A. 2016. Pengaruh Berbagai Pembenah Tanah Terhadap Pertumbuhan dan Populasi Tanaman Padi Sawah (Oryza Sativa L) Varietas Dendang di Tanah Salin Sawah Bukaan Baru. Jurnal Agrotek Indonesia. 1(2). https:// doi.org/10.33661/jai.v1i2.346
Park HJ, Kim WY, Pardo JM, Yun DJ. 2016. Molecular Interactions Between Flowering Time and Abiotic Stress Pathways. International review of cell and molecular biology. Elsevier. 371-412. https:// doi.org/10.1016/bs.ircmb.2016.07.001

Purwaningrahayu RD. 2016. Karakter Morfofisiologi dan Agronomi Kedelai Toleran Salinitas. Iptek Tanaman Pangan. 11(1): 35-48.

Purwaningrahayu RD, Taufiq A. 2017. Respons morfologi empat genotip kedelai terhadap cekaman salinitas. Jurnal Biologi Indonesia. 13(2):175-188.

Raja W, Rathaur P, John SA, Ramteke PW. 2012. Azolla: An Aquatic Pteridophyte With Great Potential. International Journal of Research in Biological Sciences. 2(2): 68-72.

Suárez-Hernández AM, Vázquez-Angulo JC, Grimaldo-Juárez O, Ceceña-Durán C, GonzálezMendoza D, Bazante-González I, Mendoza-Gómez A. 2019. Production and quality of grafted watermelon in saline soil. Horticultura Brasileira. 37(2): 215-219. https://doi.org/10.1590/s0102053620190213

Temel S, Keskin B, Şimkek U, Yilmaza IH. 2016. The Effect of Saline and Non-Saline Soil Conditions on Yield and Nutritional Characteristics of Some Perennial Legumes Forages. Journal of Agricultural Sciences. 22: 528-538. https://doi.org/10.1501/ Tarimbil_0000001411

Thohiron M, Prasetyo H. 2012. Pengelololaan Lahan dan Budidaya Tanaman Lahan Terdampak Lumpur Marine Sidoarjo. Indonesian Journal of Environment and Sustainable Development. 3(1): 19-27.

Utama MZH, Haryoko W, Munir R, Sunadi. 2009. Penapisan Varietas Padi Toleran Salinitas pada Lahan Rawa di Kabupaten Pesisir Selatan. Jurnal Agronomi Indonesia (Indonesian Journal of Agronomy). 37(2): 101-106. https://doi.org/10. 24831/jai. v37i2.1401

Wahyuningsih S, Kristiano A, Taufiq A. 2017. Pengaruh Jenis Amelioran terhadap Pertumbuhan dan Hasil Kacang Hijau di Tanah Salin. Buletin Palawija. 15: 69-77. https://doi.org/10.21082/bulpa.v15n2. 2017.p69-77

Zeng L, Shannon MC, Grieve CM. 2002. Evaluation of Salt Tolerance in Rice Genotypes by Multiple Agronomic Parameters. Euphytica. 127(2): 235-245. https://doi.org/10.1023/A:10202629 32277

Zhu JK. 2001. Plant Salt Tolerance. Trends Plant Science. 6(2): 66-71. https://doi.org/10.1016/ S1360-1385(00)01838-0 